\title{
Author Index Volume 13
}

Akankwasa, K., Ortmann, G. F., Wale, E. and Tushemereirwe, W. K., Early-Stage Adoption of Improved Banana "Matooke" Hybrids in Uganda: A Count Data Analysis Based on Farmers' Perceptions

Alghadeer, A. and Mohamed, S., Diffusion of Organisational Innovation in Saudi Arabia: The Case of the Project Management Office $(P M O)$

Anderson, T. R., see Wang, B.

Asgary, N. and Thamhain, H., Leadership Lessons from Managing Multinational Project Teams

Basak, E., see Calisir, F.

Beckman, P., see Mak, B.

Bhowmick, B., see Hukampal, S. S.

Bifulco, F., see Spena, T. R.

Bohn, N., see Mak, B.

Brun, E. C., Ambidexterity and Ambiguity: The Link Between Ambiguity Management and Contextual Ambidexterity in Innovation

13 (2016) 1650001

13 (2016) 1650019

13 (2016) 1650006

13 (2016) 1650007

13 (2016) 1640001

13 (2016) 1650010

13 (2016) 1650016

13 (2016) 1640013

13 (2016) 1650010

Calisir, F., Gumussoy, C. A., Basak, E. and Gurel, G., Effect of Organizational Learning, Transformational Leadership, and Market Orientation on Firm Performance

Ceci, F., Masciarelli, F. and Prencipe, A., Changes in Organizational Architecture: Aspiration Levels, Performance Gaps and Organizational Change

Corso, M., see Gastaldi, L.

Del Vecchio, P., see Secundo, G.

Deng, F. J., see Mackey, J. T.

Elangovan, N., Mediation of Perceived Innovation Characteristics on ERP Adoption in Industrial Cluster

Elia, G., Margherita, A. and Petti, C., An Operational Model to Develop Technology Entrepreneurship "EGO-System"

Gastaldi, L. and Corso, M., Academics as Orchestrators of Innovation Ecosystems: The Role of Knowledge Management

Ghyas, Q. M. and Kondo, F. N., How Do Mobile Information

Services Improve Quality of Life? The Case of Japanese Students Grover, S., see Singh, B.

13 (2016) 1650013

13 (2016) 1640001

13 (2016) 1650002

13 (2016) 1640009

13 (2016) 1640012

13 (2016) 1640002

13 (2016) 1640003

13 (2016) 1640008

13 (2016) 1640009

13 (2016) 1750002

13 (2016) 1750005 
Gumussoy, C. A., see Calisir, F.

13 (2016) 1640001

Guo, Y., see Zheng, G.

13 (2016) 1640014

Gurel, G., see Calisir, F.

13 (2016) 1640001

Haasis, H.-D., see Kilubi, I.

13 (2016) 1650008

Häckel, B., Lindermeir, A., Moser, F. and Pfosser, S., Evaluating Different IT Innovation Investment Strategies from an Ex Ante and Ex Post Evaluation Perspective

Hasse, R. and Passarge, E., Institutions, Dominant Actors, and Financial Markets: The Case of Venture Capital for Biotechnology in Switzerland

Hukampal, S. S. and Bhowmick, B., Innovation Network for Entrepreneurship Development in Rural Indian Context: Exploratory Factor Analysis

Johnson, J. L., see Tong, P.

Kannattukunnel, R. S., Global Patents on 3D Printing: Revelations Based on Vector Autoregression Analysis for Three Decades

Kehrel, U., Klischan, K. and Sick, N., Why Research Partnerships Fail in the Biotechnology Sector - An Empirical Analysis of Strategic Partnerships

13 (2016) 1650015

13 (2016) 1750001

13 (2016) 1650016

13 (2016) 1640006

13 (2016) 1750004

13 (2016) 1650003

13 (2016) 1650017

Kilubi, I. and Haasis, H.-D., 26 Years of Strategic Technology Partnering: Investigating Trends, Patterns and Future Prospects in Research Through Frequency Analysis

Kim, J. S., An Investigation of Key Factors Affecting the Adoption of Smartphone in Three Regions

Kimzan, H. S., see Uzkurt, C.

Klischan, K., see Kehrel, U.

Kondo, F. N., see Ghyas, Q. M.

Lee, R. P., see Tong, P.

Lee, Y.-T., see Yeh, C.

Lee, Y.-T., see Yeh, C.

Lichtenthaler, U., The Role of Unabsorbed Slack in Internal and Collaborative Innovation Processes: A Resource-Based Framework

13 (2016) 1650008

13 (2016) 1640017

13 (2016) 1750003

13 (2016) 1650003

13 (2016) 1750002

13 (2016) 1640006

13 (2016) 1650004

13 (2016) 1650009

Lichtenthaler, U., Manage Your Company's Innovation Interdependencies

Lindermeir, A., see Häckel, B.

Lu, L., see Xu, Y.-H.

Mackey, J. T. and Deng, F. J., Examining the Role of Management Control Systems in the Creation of an Innovative Culture

Mak, B., Beckman, P. and Bohn, N., Perceived Usefulness and Satisfaction of Mobile Phone for Users with Disabilities

13 (2016) 1640007

13 (2016) 1750007

13 (2016) 1650015

13 (2016) 1640016

13 (2016) 1640002

Margherita, A., see Elia, G.

13 (2016) 1650010

13 (2016) 1640008

13 (2016) 1650002

13 (2016) 1650012

Minutolo, M. C., see Yang, Q.

Mohamed, S., see Alghadeer, A.

13 (2016) 1650019 
Morales-Alonso, G., Pablo-Lerchundi, I. and Vargas-Perez, A. M., An Empirical Study on the Antecedents of Knowledge Intensive Entrepreneurship

13 (2016) 1640011

Moser, F., see Häckel, B.

Na, J. and Sun, Y., How do Multinationals Exploit Technologies in 13 (2016) 1650015 the Global Market?

Ndou, V., see Secundo, G.

Ortmann, G. F., see Akankwasa, K.

Özkan, B. Y., see Temiz, A. Ş.

Pablo-Lerchundi, I., see Morales-Alonso, G.

Pandey, S. C., see Pattnaik, P. N.

Passarge, E., see Hasse, R.

Pattnaik, P. N. and Pandey, S. C., Revisiting University Spinoffs: Conceptual Advancements and Theoretical Underpinnings

Petti, C., see Elia, G.

Pfosser, S., see Häckel, B.

Prencipe, A., see Ceci, F.

Ridgman, T., see Thorpe, M.

Schröder, M., see Skirde, H.

Secundo, G., Ndou, V. and Del Vecchio, P., Challenges for Instilling Entrepreneurial Mindset in Scientists and Engineers: What Works in European Universities?

Sick, N., see Kehrel, U.

Singh, B., Grover, S. and Singh, V., Integrated MCDM for Benchmarking Techniques in Indian Service Industries

Singh, V., see Singh, B.

Skirde, H., Kersten, W. and Schröder, M., Measuring the Cost Effects of Modular Product Architectures - A Conceptual Approach

Spena, T. R., Trequa, M. and Bifulco, F., Knowledge Practices for an Emerging Innovation Ecosystem

Sun, Y., see Na, J.

Tajeddini, K., Financial Orientation, Product Innovation and Firm Performance: An Empirical Study in the Japanese SMEs

Temiz, A. Ş., Özkan, B. Y. and Üçer, A. Ş., A Product-Based Strategic Technology Management Methodology for Developing Countries

Thamhain, H., see Asgary, N.

Thorpe, M. and Ridgman, T., Identifying and Sharing the Knowledge Required for Scaling Up Innovative Technologies in the Process Industry

Tong, P., Umesh, U. N., Johnson, J. L. and Lee, R. P., Collaborative Relationships: The Role of Information Technology

Trequa, M., see Spena, T. R.

Tsai, C.-F., see Yung, I.-S.

Tushemereirwe, W. K., see Akankwasa, K.

Üçer, A. Ş., see Temiz, A. Ş.

Umesh, U. N., see Tong, P.

13 (2016) 1640004

13 (2016) 1640012

13 (2016) 1650001

13 (2016) 1650011

13 (2016) 1640011

13 (2016) 1650005

13 (2016) 1750001

13 (2016) 1650005

13 (2016) 1640008

13 (2016) 1650015

13 (2016) 1650002

13 (2016) 1750006

13 (2016) 1650017

13 (2016) 1640012

13 (2016) 1650003

13 (2016) 1750005

13 (2016) 1750005

13 (2016) 1650017

13 (2016) 1640013

13 (2016) 1640004

13 (2016) 1640005

13 (2016) 1650011

13 (2016) 1650007

13 (2016) 1750006

13 (2016) 1640006

13 (2016) 1640013

13 (2016) 1650018

13 (2016) 1650001

13 (2016) 1650011

13 (2016) 1640006 
Uzkurt, C., Kimzan, H. S. and Yilmaz, C., A Case Study of the Mediating Role of Innovation on the Relationship Between Environmental Uncertainty, Market Orientation, and Firm Performance

13 (2016) 1750003

van der Meer, H., Entrepreneurs, Art and Innovation

13 (2016) 1640010

Vargas-Perez, A. M., see Morales-Alonso, G.

Wale, E., see Akankwasa, K.

Wang, B., Anderson, T. R. and Zehr, W., Competitive Pricing Using Data Envelopment Analysis - Pricing for Oscilloscopes

Wang, Y., see Zheng, G.

Wonglimpiyarat, J., Technological Change of the Innovation Payment System

13 (2016) 1640011

13 (2016) 1650001

13 (2016) 1650006

13 (2016) 1640014

13 (2016) 1650014

$\mathrm{Xu}, \mathrm{Y} . \mathrm{-H} ., \mathrm{Lu}, \mathrm{L}$. and Yao, Z.-X., Culture and Creative Industry in China: Critical Review on the Current Research Trends and Future Development

13 (2016) 1640016

Yang, Q. and Minutolo, M. C., The Strategic Approaches for a New Typology of Firm Patent Portfolios

Yao, Z.-X., see Xu, Y.-H.

Yeh, C. and Lee, Y.-T., Change Control of Key Capability Factors in Product Research and Development

Yeh, C. and Lee, Y.-T., Designing Pre-Reaction Production Mechanism for Traditional and Postponed Dyeing in Apparel Supply Chain

Yılmaz, C., see Uzkurt, C.

Yung, I.-S. and Tsai, C.-F., The Effect of the Fit Between Product Architecture and Competitive Action on Business Performance: An Empirical Study of the Taiwan IT Industry

13 (2016) 1650012

13 (2016) 1640016

13 (2016) 1650004

13 (2016) 1650009

13 (2016) 1750003

13 (2016) 1650018

13 (2016) 1650006

Zheng, G., Guo, Y. and Wang, Y., Non-REDD Innovation Patterns in Chinese SMEs: An Empirical Study from Zhejiang Province

13 (2016) 1640014 